\title{
The Role of HIV Infection in the Pathophysiology of Gestational Diabetes Mellitus and Hypertensive Disorders of Pregnancy
}

\author{
Wendy N. Phoswa* \\ Department of Life and Consumer Sciences, University of South Africa (UNISA), Science Campus, Florida, South Africa
}

\section{OPEN ACCESS}

Edited by:

Modar Kassan,

University of Tennessee Health

Science Center (UTHSC),

United States

Reviewed by:

Marius Miglinas,

Vilnius University, Lithuania

Alexis A. Gonzalez,

Pontifical Catholic University of

Valparaíso, Chile

*Correspondence:

Wendy N. Phoswa

phoswawendy@gmail.com

Specialty section:

This article was submitted to

Hypertension

a section of the journal

Frontiers in Cardiovascular Medicine

Received: 04 October 2020 Accepted: 19 April 2021 Published: 12 May 2021

Citation:

Phoswa WN (2021) The Role of HIV Infection in the Pathophysiology of Gestational Diabetes Mellitus and Hypertensive Disorders of Pregnancy.

Front. Cardiovasc. Med. 8:613930.

doi: 10.3389/fcvm.2021.613930
Purpose of the Review: The main objective of this study is to investigate mechanisms associated with gestational diabetes mellitus (GDM) and hypertensive disorders of pregnancy (HDP) in HIV infected pregnant women by looking how placental hormones such as (progesterone and prolactin) and basic haemostatic parameters are regulated in HIV infected pregnancies.

Recent Findings: HIV/AIDS are a major global obstetric health burden that lead to increased rate of morbidity and mortality. HIV/AIDS has been associated with the pathophysiology of GDM and HDP. Increased risk of GDM due to highly active antiretroviral therapy (HAART) usage has been reported in HIV infected pregnancies, which causes insulin resistance in both pregnant and non-pregnant individuals. HAART is a medication used for lowering maternal antepartum viral load and pre-exposure and post-exposure prophylaxis of the infant. In pregnant women, HAART induces diabetogenic effect by causing dysregulation of placental hormones such as (progesterone and prolactin) and predispose HIV infected women to GDM. In addition to HIV/AIDS and GDM, Studies have indicated that HIV infection causes haemostatic abnormalities such as hematological disorder, deregulated haematopoiesis process and the coagulation process which results in HDP.

Summary: This study will help on improving therapeutic management and understanding of the pathophysiology of GDM and HDP in the absence as well as in the presence of HIV infection by reviewing studies reporting on these mechanism.

Keywords: gestational diabetes, gestational hypertension, highly active antiretroviral therapy, human immune deficiency virus, hypertensive disorders of pregnancy, pre-eclampsia

\section{INTRODUCTION}

Human immune deficiency virus and acquired immunodeficiency syndrome (HIV/AIDS) is the major global health burden affecting $\sim 36.9$ million people in the world, including 1.8 million children. "About 25\% people don't know their HIV status" (1). The prevalence of HIV infection is higher in low- and middle- income countries, with about 66\% living in sub-Saharan Africa. Approximately "19.6 million people are living in East and Southern Africa" (2). In 2017, there were 800,000 new HIV infections in 2017 in the Southern Africa. About 66\% adults and 59\% children are on anti-retroviral therapy (3). 
In the 1980s, the average life expectancy following HIV/AIDS diagnosis was $\sim 1$ year. However, with improved medical care; Today, availability of highly active anti retro viral therapy (HAART) started early in the course of HIV infection, have been beneficial in suppressing HIV thus reducing mortality and improving life span of HIV infected individuals (4-6). Unfortunately these drugs lead to development of other adverse health outcomes such as metabolic disorders (Insulin resistance, diabetes mellitus, dyslipidemia, and lipodystrophy) (6, 7). Several studies have reported on the incidence of diabetes mellitus (DM) in HAART experienced individuals $(8,9)$. The prevalence of DM has been reported to be $10 \%$ in HIV individuals receiving medical care, nearly $3.8 \%$ higher than in the HIV uninfected population $(10,11)$.

"Several risk factors such as aging, male sex, obesity, African American, Hispanic, Indian ethnicity, family history, and hepatitis $\mathrm{C}$ coinfection, high body mass index (BMI), greater waist circumference, and lower socioeconomic class, have been associated with the development of DM in HIV-infected individuals" (12-18). HIV infection has reported to been linked more with type 2 diabetes mellitus (T2DM) rather than type 1 diabetes mellitus (12). Another type of diabetes that has been widely associated with HIV infection in pregnancy is gestational diabetes mellitus (GDM). Several studies have reported on the incidence of GDM in HIV infected pregnant women. It is speculated that this occurs as a result of HIV infection which causes alterations in the placental hormones which are associated with insulin resistance. Additionally, human immune deficiency virus (HIV) has also been observed as a risk factor for HDP (19). Multiple studies have reported that HIV predisposes pregnant women to $\operatorname{HDP}(19,20)$. Although, the mechanism behind this remains to be ununderstood. It is believed that this occurs as a result of exposure to HAART. HAART "is a treatment given to non-pregnant and pregnant women to prevent viral replication and mother-to-child transmission" (21). This treatment has been reported to alter maternal haemostatic profile $(22,23)$.

Current literature provides enough evidence that there is a direct link between HIV infection and the pathophysiology of GDM as well HDP. Therefore, more research is required in order to understand association between HIV infection and these diseases. This will help the health care practitioners to improve diagnostic criteria's and care for HIV infected women who are suffering from GDM as well as HDP. And will also help better our knowledge and understanding on the pathophysiology of these conditions in order to improve therapeutic approaches. Hence, the main objective of this study is to investigate mechanisms associated with GDM and HDP in HIV infected pregnant women by looking how placental hormones such as (progesterone and prolactin) and basic haemostatic parameters are regulated in HIV infected pregnancies.

\section{GESTATIONAL DIABETES MELLITUS}

"Gestational diabetes mellitus (GDM), is defined as excessive glucose intolerance diagnosed during gestation" (24). This disease affects $14 \%$ of all pregnancies world-wide (25). The prevalence of GDM in high-income countries is $2-10 \%$ and $1.6-14 \%$ in low-middle-income countries $(26,27)$.

Normally, "pregnancy involves altered state of glucose metabolism and insulin sensitivity" (28). However, this change predisposes some pregnant women to $\operatorname{GDM}(18,29)$. Pregnancies affected by GDM are associated with detrimental effects on maternal and fetal health. These effects include, "risk of cesarean and operative vaginal delivery, macrosomia, preterm birth, shoulder dystocia, microangiopathy, neonatal hypoglycemia and hyperbilirubinemia, pregnancy induced hypertension, and preeclampsia" $(30,31)$. Women with a previous history of GDM have increased risk of developing T2DM at an earlier stage in life and cardiovascular diseases (32). Risk factors for GDM include family history of diabetes, advanced maternal age, obesity, ethnicity (no white ethnicity), and previous pregnancy complications (17, 18, 29). "There is currently no cure for GDM, except lifestyle intervention (balanced diet and regular exercise)" (33).

The "prevalence of GDM in HIV uninfected pregnant women is $2-5 \%$ of all pregnancies in high income countries" (34, 35 ) and $2-7 \%$ in HIV-infected pregnant women $(7,36-45)$. "Increased risk of developing GDM in HIV infected women has been reported to be due to the use of HAART which induces insulin resistance in pregnant and non-pregnant individuals" (46). Currently, studies have outlined on the pathophysiology of GDM, however the association between GDM and HIV infection remain obscure.

\section{PATHOPHYSIOLOGY OF GDM}

Gestational diabetes result from hyperinsulinemia and insulin resistance leading to abnormal glucose intolerance. During the early stages of pregnancy, various metabolic changes occur in the order to promote adipose tissue accumulation. "These changes include increased insulin secretion and insulin sensitivity" (29). Some studies report that insulin sensitivity remain unchanged or decreased during early stages of pregnancy $(47,48)$. However, "In later stages of pregnancy, insulin sensitivity is reduced due to activation of a number of hormones such as placental lactogen, estrogen, leptin, progesterone, prolactin, cortisol, and adiponectin. It has been reported that insulin resistance plays a central role in the pathophysiology of $\operatorname{GDM}^{\prime \prime}(49,50)$.

\section{Placental Induced Insulin Resistance}

In the placenta, insulin binds to insulin receptors (IRs) which are present in the placental cells (cytotrophoblasts), thus activating the signaling pathways such as the Ras-extracellular-signalregulated kinase (Ras-ERK) and the IRS (IR substrate)-PI3KAkt-mTOR pathway, which are important for placental cellular differentiation, proliferation and metabolism of nutrients (5153). Insulin is not the only hormone responsible for activating these pathways, growth factors and placental hormones, also play a very important role in their activation (54-56).

During normal pregnancy development the placenta secretes several hormones such as human placental lactogen (hPL), human placental growth hormone (hPGH), progesterone, adiponectin, leptin, prolactin, and cortisol into the maternal blood systems (57). These hormones play a very crucial role 
in fetoplacental development. However, over secretion as well as under secretion of these hormones has been associated with reduced insulin sensitivity during pregnancy $(49,57,58)$.

\section{Human Placental Lactogen or Human or Chorionic Somatomammotropin Hormone}

Human placental lactogen (hPL) has been shown to "induce insulin secretion from the pancreases during pregnancy" (59). Various studies have documented that hPL can induce insulin resistance $(60,61)$. Additionally, other studies indicate that hPL can cause peripheral lipolysis insulin resistance $(62,63)$, although the results are debatable (64). A study conducted by Vasavada et al. (65) in Beta cells of transgenic mice showed that placental lactogen (PL) resulted in over secretion of plasma insulin. Interestingly they also observed increased (2-fold) insulin content in the pancreas. Similar findings were observed by Parsons et al. (66) where they found that placental lactogen secretion resulted in increased islet cell proliferation and insulin secretion. Although, studies have reported on the role of placental lactogen on insulin resistance, However very few studies have reported on human placenta (Table 1). Therefore, more studies looking at the role of human placental lactogen on insulin resistance in different ethnics groups are needed.

\section{Human Placental Growth Hormone}

The human placental growth hormone (hPGH) is found in the placental cells (syncytiotrophoblast), and is said to "replace pituitary growth hormone during pregnancy" (78). This hormone has also been implicated to induce diabetogenic effects result from increased glucose levels and insulin resistance (60, 79). A study conducted by Barbour et al. (68) showed that "hPGH may lead to insulin resistance by increasing the expression of the $\mathrm{p} 85 \alpha$ monomer, which inhibits p 85 -p110 heterodimer from binding to insulin receptor substrate-1 (IRS-1) protein" (67) thus preventing further insulin signaling leading to substantially reduced glucose uptake $(80,81)$. "IRS-1 interacts with the p85-p110 heterodimer of phosphatidylinositide 3-kinase (PI3K) which then leads to the activation of this enzyme and subsequent stimulation of adenylate kinase 3 (Akt), resulting in enhanced glucose utilization, and increased glycogen and protein synthesis" $(82,83)$.

It has been reported that "GDM patients had decreased levels of IRS-1" (49) indicating that in DGM patients there is increased levels of insulin resistance.

\section{Progesterone}

According to Costrini and Kalkhoff (84) "Progesterone contribute to increased insulin secretion and plasma insulin sensitivity to glucose administration during pregnancy." Several studies have reported on the diabetogenic effect of progesterone (69-72, 85, 86). Rebarber et al. (87) observed that Administration of progesterone compound; prophylactic intramuscular $17 \alpha-$ Hydroxyprogesterone (17P) resulted in $12.9 \%$ incidence of GDM compared to $4.9 \%$ control groups. Implying that " $17 \mathrm{P}$ is associated with an increased risk of GDM". In contrast a study done by Rosta et al. (88); evaluating the effect of vaginal administration of progesterone on the incident of GDM, showed that there was no significance difference on the incidence of GDM in progesterone treated and the control group. They further concluded that "the use of progesterone is not linked with an increased risk of GDM" (88).

\section{Adiponectin}

Adiponectin, "is an insulin-inducing hormone secreted by adipose tissue" (89). It is been associated with the pathogenesis of insulin resistance (90). Low levels of adiponectin lead to insulin resistance thus resulting in the pathophysiology of $\operatorname{GDM}(49,91)$.

Studies have shown that the risk of GDM is higher in women with reduced adiponectin levels $(92,93)$. The general function of adiponectin is to "facilitates insulin action through binding to its receptors AdipoR1 and AdipoR2, thereby leading to induction of adenosine monophosphate dependent kinase (AMPK), PPAR- $\alpha$ " (94).

Adiponectin induces antidiabetic effects by stimulating glucose uptake via AMPK by "binding to its receptors AdipoR1 and AdipoR2" (95). "This reduces glucose production in the liver, which can account for the antidiabetic effects of adiponectin" (95). A case control study done by Mohammadi and Paknahad (73) showed decreased serum concentration levels of adiponectin in GDM women indicating adiponectin as a diagnostic tool for detecting the presence of GDM. Although, there are very few studies (96) that have reported on the role of adiponectin on the pathogenesis of insulin resistance in GDM (Table 1), more studies are needed in order to understand how adiponectin is regulated in GDM patients.

\section{Leptin}

"Is a hormone produced by adipocytes and in low levels by the gastric fundic intestine, placenta, skeletal muscle, and brain" (94, 97). Leptin is important for glucose homeostasis (94). Administration of leptin have been reported to lower insulin secretion (98-102).

A study done in vitro showed that "leptin can prevent glucose transporter 2 (GLUT2) phosphorylation, glucose transport, and intracellular adenosine triphosphate (ATP) levels" (98).

Leptin has also been shown to "reduce cyclic adenosine monophosphate (cAMP)-induced insulin secretion, via stimulation of phosphodiesterase-3B (PDE3B") (103-105). Leptin also inhibits protein kinase $\mathrm{C}(\mathrm{PKC})$-induced insulin secretion (106).

The function of leptin is "mediated by the Janus kinase, signal transducer and activator of transcription (JAK-STAT) pathway" (94). "Leptin receptor-mediated JAK-STAT signaling is crucial for monitoring of food ingestion and body weight" (94). Leptin also stimulate PI3K which in turn stimulate IRS-1 followed which activate insulin secretion allowing glucose uptake by the cells (94).

The levels of leptin in diabetes are remain debatable. Several studies report higher plasma leptin levels diabetes mellitus (96, $107,108)$. In contrast, Some studies report that reduced levels of leptin correlates with type 1 diabetes (109). However, some studies indicate that there is no correlation between plasma leptin levels and diabetes $(110,111)$. Interestingly, some research 
TABLE 1 | A comprehensive list of studies in this review reporting on hormones associated with GDM.

\begin{tabular}{|c|c|c|c|c|}
\hline Hormone investigated & Author & Country & Cohort type & Main findings \\
\hline Human placental lactogen (hPL) & $(66)$ & United States & $\begin{array}{l}\text { Rat pancreatic cells (islets of } \\
\text { Langerhans) }\end{array}$ & hPL increased insulin secretion. \\
\hline Human placental lactogen (hPL) & (59) & United States & $\begin{array}{l}\text { Rat, mouse, and human } \\
\text { pancreatic cells (islets of } \\
\text { Langerhans) }\end{array}$ & $\mathrm{hPL}$ induces insulin resistance during pregnancy. \\
\hline Human placental lactogen (hPL) & $(65)$ & United States & Mice & $\begin{array}{l}\text { hPL increased plasma insulin and pancreatic insulin } \\
\text { secretion. }\end{array}$ \\
\hline $\begin{array}{l}\text { Human placental growth } \\
\text { hormone }(\mathrm{hPGH})\end{array}$ & $(67)$ & United States & Mice & hPGH may contribute to the insulin resistance. \\
\hline Progesterone & (68) & United States & Pregnant women & $\begin{array}{l}\text { The use of 17alpha-hydroxyprogesterone caproate } \\
\text { (17P) predisposes women to GDM. }\end{array}$ \\
\hline Progesterone & (69) & United States & Pregnant women & $\begin{array}{l}\text { Women receiving weekly intramuscular } \\
\text { 17alpha-hydroxyprogesterone had increased } \\
\text { prevalence of GDM. }\end{array}$ \\
\hline Progesterone & $(70)$ & Brazil & $\begin{array}{l}\text { Rat pancreatic cells (islets of } \\
\text { Langerhans) }\end{array}$ & $\begin{array}{l}\text { Progesterone leads to pancreatic cells oxidative } \\
\text { stress and may be associated with gestational } \\
\text { diabetes in pregnancy. }\end{array}$ \\
\hline Progesterone & $(71)$ & United States & Pregnant women & $\begin{array}{l}\text { In obese women, the use of } \\
\text { 17alpha-hydroxyprogesterone caproate (17P) may } \\
\text { increase their chances of developing GDM. }\end{array}$ \\
\hline Progesterone & $(72)$ & Iran & Pregnant women & $\begin{array}{l}\text { The use of } 17 \text { alpha-hydroxyprogesterone caproate } \\
(17 \mathrm{P}) \text { may associated with increased risk of GDM in } \\
\text { women who conceived via assisted reproductive } \\
\text { technology. }\end{array}$ \\
\hline Adiponectin & (73) & Iran & Pregnant women & Adiponectin is lower in gestational diabetic women. \\
\hline Leptin & $(74)$ & Austria & Pregnant women & Leptin is correlated with insulin resistance. \\
\hline Leptin & $(75)$ & Iran & Pregnant women & Leptin is higher in GDM. \\
\hline Leptin & $(76)$ & China & Pregnant women & Leptin is associated with GDM. \\
\hline Prolactin & $(77)$ & Australia & Pregnant women & $\begin{array}{l}\text { High prolactin is associated with higher glucose and } \\
\text { the pathogenesis on GDM. }\end{array}$ \\
\hline
\end{tabular}

findings report that diabetogenic effect of plasma leptin was only observed in men than women $(96,112,113)$.

A study by Kautzky-Willer et al. (74) showed that "high serum leptin levels were correlated with insulin resistance in GDM." These findings were confirmed by Soheilykhah et al. (75) who observed similar correlation. More interestingly, a study conducted by Yang et al. (76) in Chinese population, investigating the "association between gestational diabetes and plasma leptin levels, leptin G2548, and leptin receptor Gln223Arg polymorphisms" showed that "GDM was only associated with high plasma leptin levels rather that leptin Gln223Arg and leptin receptor polymorphisms." Although, studies have reported on the association between plasma leptin levels and GDM, however, there are currently no studies that have reported on the association between leptin levels and GDM in the African population (Table 1). More studies are needed in order to see how plasma leptin levels, leptin, and leptin receptor gene polymorphisms are expressed in the African population.

\section{Prolactin}

Prolactin is a "hormone has also been shown to play role in maintaining glucose homeostasis" (114). Association between prolactin levels and the risk of GDM remain controversial. Some studies report that "excessive prolactin levels have been associated with insulin resistance in diabetes" (115), and some report that "high prolactin levels are associated with decreased risk of diabetes mellitus and impaired glucose tolerance" (116). A prospective study conducted by Wang et al. (117) showed that "high circulating prolactin levels are associated with reduced incident of diabetes mellitus." In contrast, Daimon et al. (118) showed that "high serum prolactin levels is associated with metabolic effect such as insulin insensitivity in Men."

Very few studies have associated the levels of prolactin with GDM. High prolactin levels have been linked to the pathogenesis of GDM (77). In contrast, Retnakaran et al. (119) documented that high prolactin levels indicate a sign of lower chances to develop diabetes. Therefore, more studies are needed to confirm how prolactin levels are regulated in GDM.

\section{Cortisol}

Other factors such as "increased levels of serum cortisol" (120), "Tumor necrosis factor $\alpha$ (TNF $\alpha$, ILs e.g., IL-6), can interrupt the insulin signaling pathway and can lead to insulin resistance during normal pregnancy" (121). 


\section{PATHOPHYSIOLOGY OF GDM IN HIV ASSOCIATED PREGNANCIES}

HIV/AIDS has been shown to be the global pandemic that lead both maternal and perinatal morbidity and mortality resulting from pregnancy related complications such as GDM. The placenta is believed to play a primary role in the pathogenesis of gestational diabetes. The placenta is a highly specialized organ that is responsible for normal pregnancy development. It allows feto-maternal exchange of gases and nutrients for fetal development and maintenance to occur. Various pathogens, such as bacterial, fungal, and virus infection (e.g., HIV) can disturb the normal performance of the placenta and lead to pregnancy related complications.

HAART usage during HIV infected pregnancies has been mentioned as the key factor that lead to pregnancy related complications (122-124). HAART-induced GDM is believed to result from the dysregulation of placental hormones during pregnancy. Several studies have reported on how these hormones are regulated in during HIV infection and in the duration of HAART.

Placenta development is regulated by progesterone $(125,126)$. Reduced levels of progesterone in HIV infection has been reported to disrupt normal pregnancy development (127).

Previous studies have shown that "progesterone levels are lower in HAART treated HIV-infected pregnant women" $(128,129)$, this explain why there is an increase rate of pregnancy complications in HIV associated pregnancies. A study conducted by Mohammadi et al. (130) on mice revealed that progesterone supplementation to HAART-treated mice improved their placental function. Currently, there are no studies that have reported on the levels of progesterone in HIV associated GDM women. Studies are needed in order to see how this hormone is regulated in HIV induced metabolic disorders.

Leptin is another hormone that has been reported in HIV associated metabolic disorders. This hormone is known for it anti-diabetogenic effects (131). Leptin levels are generally higher in females than in male population (132). In women, leptin levels increase drastically during pregnancy and decrease before or during labor (133).

There is contradictory data on levels of leptin in HIV associated studies. A previous study has reported that leptin levels are decreased in HIV/HAART-associated lipoatrophy (134). In contrast Haffejee et al. (135), observed that high leptin levels in HIV-infected HAART treated women is associated with the pathogenesis of a pregnancy complication (pre-eclampsia). To the best of our knowledge, no studies have reported on the levels of leptin in in HIV infected gestational diabetic women. More studies are needed evaluating the levels of leptin in HIV associated metabolic disorders.

Prolactin is also another hormone that has been found to be elevated during HIV infection $(136,137)$, but not correlated to HAART usage (138). In contrast, Okeke et al. (139) indicated that prolactin levels are suppressed in HIV infected pregnancy women and that HAART had no effect on the levels of prolactin. No studies have reported on how prolactin in regulated in the presence of HIV infection in GDM women. Therefore, studies are needed in order to understand the pathophysiology underlying GDM during HIV infection.

More interestingly, metabolic disturbance in HIV infected individuals has been correlated with increased serum cortisol. Collazos et al. (140), showed that HIV infected patients who initiated HAART had elevated serum cortisol levels. These findings confirmed the role of cortisol on the metabolic disorders induced by HAART during HIV infection.

In addition, a study evaluating the levels of hPGH showed that HIV status had no effect on the levels of this hormone. These findings were in accordance with the findings by Esemu et al. (141), who investigated the effect of HIV infection on insulin-like growth factor-1 (IGF-1) and angiogenic factors in Cameroonian pregnant women receiving HAART. They reported that "HIV infection did not alter the regulation of both factors" (141). Their findings also confirmed the important of HAART usage in maintaining IGF-1 during pregnancy (141). "IGF-1 is a primary mediator of growth hormone" and placental growth hormone (142). It is also involved in stimulating insulin signaling pathway via activation of PI3K-AKT pathway. However, more studies are still needed in order to validate how this hormone is regulated in the presence of HIV infection.

Apart from GDM, HIV infection and its association with increased risk of hypertensive disorders of pregnancy has been reported (19).

\section{HYPERTENSIVE DISORDERS OF PREGNANCY}

Affect up to $10 \%$ of all pregnancies globally (143). The "HDP comprise of gestational hypertension $(\mathrm{GH})$, preeclampsia (PE) and eclampsia (E). A majority of HDP cases are from low and middle income countries" (144). In South Africa, "HDP are the most common direct cause of maternal mortality and account for $18 \%$ of all maternal deaths" $(145,146)$. Hypertensive disorders of pregnancy can also "affect the fetus and the newborn by leading to premature delivery, intrauterine growth retardation (IUGR), abruptio placentae and intrauterine death" (147). "Maternal complications include the HELLP syndrome (hemolyisis, elevated liver enzymes, low platelets), pulmonary edema, acute liver/renal failure, disseminated intravascular coagulopathy, adult respiratory distress syndrome, sepsis, and liver hemorrhage" (144). Despite extensive research on HDP, the pathophysiology of this disorder remains an egnima. Inflammation is one of the commonly reported factors that lead to the development of HDP (148). Among other factors reported to be involved in the pathophysiology of HDP is haemostatic (hematology and coagulation) profile. Studies have demonstrated that "neutrophil to lymphocyte ratios and platelet count may predict disease development, and may help in monitoring disease and the prognosis of HDP" (149-154).

Several risk factors are associated with the pathogenesis HDP. These factors include previous history of PE or GH, multiple pregnancies, polycystic ovarian syndrome, chronic kidney disease, hypertension, diabetes, and autoimmune disorders (155). 
Recently, HIV has also been observed as a risk factor for HDP (19). Multiple studies have reported that HIV predisposes pregnant women to $\operatorname{HDP}(19,20)$. Although, the mechanism behind this is still to be elucidated. It is believed that this occurs as a result of exposure to highly active antiretroviral therapy (HAART). HAART is a treatment given to non-pregnant and pregnant women to prevent viral replication and motherto-child transmission (21). This treatment has been reported to induce maternal pro-inflammatory profile, thereby leading to hypertension related disorders of pregnancy $(20,156,157)$. Although many studies have focused on the effect of HAART on inflammatory response as the primary cause of HDP in HIV infected individuals. To the best of our knowledge they are very few studies that have reported on the effect of this treatment on the haemostatic profile in association to HDP.

\section{THE ROLE OF HIV INFECTION ON HAEMOSTATIC PROFILE AND HYPERTENSIVE DISORDERS OF PREGNANCY}

HIV has been identified to be strongly linked with haemostatic abnormalities such as hematological disorder, dysregulated haematopoiesis process, and the coagulation process $(22,23)$. The pathophysiological mechanism behind this link is believed to be through endothelial dysfunction $(23,158)$. Endothelial dysfunction not only affects haemostatic profile, but is also widely associated with $\operatorname{HDP}(159,160)$.

\section{Endothelial Dysfunction in Hypertensive Disorders of Pregnancy}

"The maternal vascular endothelium is a principal factor involved in the pathogenesis of HDP" (159, 161-165). Under normal conditions there is a balance in the endothelium relaxing and contractile factors that play a pivotal role in regulating arterial compliance, vascular resistance, and blood pressure. However, under abnormal conditions such as HDP, there is an imbalance of these factors. This results to damaged blood vessels which end results leads to endothelial dysfunction which is involved in the pathophysiology of HDP (161-163).

\section{Markers of Endothelial Dysfunction Associated With the Pathophysiology of HDP}

Several markers of endothelial dysfunction have been associated with HDP (166-168). These markers are "endothelin-1 (ET-1), soluble vascular adhesion molecule and interleukin-8, ELAM, and endothelial leukocyte adhesion molecule-1. Endothelin-1 is widely reported to be associated with the pathophysiology of PE" (169-172). These studies have shown that "ET-1 is increased in PE" compared to normotensive pregnancies (168, 173-175). Interestingly, it has been reported that "endothelial dysfunction may also lead to diseases associated with maternal liver and brain" (176-178). Severe forms of PE affecting the liver include HELLP syndrome (hemolysis, elevated liver enzymes, low platelet count) (176). A study by Lind et al. (179) indicated that there is correlation between ET-1 and HELLP syndrome in PE. More interestingly, a study of hypertension in an animal model also revealed that there was a strong association between HELLP syndrome and ET-1 activation (180). Eclampsia is another sever form of PE which is accompanied by the presence of seizures $(177,178,181)$. The pathophysiology of eclampsia is also reported to involve ET-1, however studies demonstrating this association are lacking. HIV infection has also been identified as a major factor contributing to endothelial dysfunction. Reports on the role of ET-1 on other HDP such as GH are also lacking. Therefore, more studies are needed in order to have a full understanding of the role of ET-1 on the pathophysiology of HDP. Apart from markers associated with endothelial dysfunction in HDP, HIV infection is another identified marker associated with endothelial dysfunction $(182,183)$.

\section{The Role of HIV Infection on Endothelial Dysfunction}

The role of HIV infection on endothelial dysfunction has been reported to result from "interaction of HIV with host cells that consist of the CD4 receptor, coreceptor chemokines ligand 4 (CXCR4), and chemokines receptor 5 (CCR5)" (184, 185). This interaction occurs with "the help of Glycoprotein 120 (gp120)" (184, 185). This leads to reduced nitric oxide expression followed by endothelial dysfunction $(184,185)$. Several studies have associated HIV infection with endothelial dysfunction (182, 183). Funderburg et al. (182) reported that "higher plasma HIV RNA levels associates with endothelial dysfunction in HIVinfected patients." Similarly, "a mouse model expressing HIV viral proteins env, tat, nef, vpu, vpr, and rev demonstrated aortic endothelial dysfunction and increased arterial stiffness" (183). Interestingly, a study by Solages et al. (186), demonstrated that HIV-infected patients had significantly impaired endothelial function, which result from disturbances in their coagulation system as demonstrated by vasoconstriction in comparison to the HIV-uninfected group.

\section{Role of HIV Infection on Coagulation}

"Endothelial cells produce different molecules that are involved in clotting and fibrinolysis process" (187). These molecules are "Willebrand factor (vWF), tissue plasminogen activator, plasminogen activator inhibitor, and protein S” (187). In HIVinfected individuals, "endothelial abnormality is a common disorder induced by the action of the virus and virus-associated inflammatory response" (188). Such endothelial abnormality "activates the coagulation system, leading to the consumption of coagulation factors" (188). Moreover, it is reported that the levels of vWF are increased in HIV (189). Similar findings have been reported in HDP $(190,191)$. Therefore, more research on vWF in HIV associated HDP is needed in order to provide possible association between the role of HIV infection in HDP.

\section{CONCLUSION}

The findings of this review indicate that placental hormones increases insulin resistance during pregnancy however there is very limited data on studies evaluating how these hormones 
are regulated in HIV infected pregnant women more studies are needed especially from African countries since there is high prevalence of HIV infection as well as high incidences maternal and fetal complication.

\section{STRENGTH OF THE STUDY}

This manuscript highlights on the role of HIV infection in GDM and HDP by looking at hormones associated with GDM and haemostatic parameters associated with HDP in both HIV infected and uninfected pregnancies.

\section{REFERENCES}

1. HIV/AIDS JUNPo. Communities at the Centre: Global AIDS Update 2019. Geneva: UNAIDS. (2019).

2. UNAIDS.AIDSinfo. UNAIDS 2019 Estimates. UNAIDS (2019).

3. HIV/AIDS JUNPo. Geneva: UNAIDS 2018. (cited December 19, 2018). Available online at: https://www.unaids.org/sites/default/files/media_asset/ unaids-data-2018_en.pdf

4. Porter K, Babiker A, Bhaskaran K, Darbyshire J, Pezzotti P, Porter K, et al. Determinants of survival following HIV-1 seroconversion after introduction of HAART. Lancet. (2003) 362:1267-74. doi: 10.1016/S0140-6736(03)14570-9

5. Palella FJ Jr, Delaney KM, Moorman AC, Loveless MO, Fuhrer J, Satten GA, et al. Declining morbidity and mortality among patients with advanced human immunodeficiency virus infection. N Engl J Med. (1998) 338:85360. doi: 10.1056/NEJM199803263381301

6. Dagogo-Jack S. New drugs and diabetes risk: antipsychotic and antiretroviral agents. Clin Diabetes. (2006) 56981. doi: 10.1016/B978-1-4160-0273-4.50047-3

7. Watts DH, Balasubramanian R, Maupin RT Jr, Delke I, Dorenbaum A, Fiore S, et al. Maternal toxicity and pregnancy complications in human immunodeficiency virus-infected women receiving antiretroviral therapy: PACTG 316. Am J Obstet Gynecol. (2004) 190:506-16. doi: 10.1016/j.ajog.2003.07.018

8. Samaras K, Wand H, Law M, Emery S, Cooper D, Carr A. Prevalence of metabolic syndrome in HIV-infected patients receiving highly active antiretroviral therapy using International Diabetes Foundation and Adult Treatment Panel III criteria: associations with insulin resistance, disturbed body fat compartmentalization, elevated Creactive protein, and hypoadiponectinemia. Diabetes care. (2007) 30:113-9. doi: $10.2337 / \mathrm{dc} 06-1075$

9. Takarabe D, Rokukawa Y, Takahashi Y, Goto A, Takaichi M, Okamoto $\mathrm{M}$, et al. Autoimmune diabetes in HIV-infected patients on highly active antiretroviral therapy. J Clin Endocrinol Metab. (2010) 95:405660. doi: 10.1210/jc.2010-0055

10. Hernandez-Romieu AC, Garg S, Rosenberg ES, Thompson-Paul AM, Skarbinski J. Is diabetes prevalence higher among HIV-infected individuals compared with the general population? Evidence from MMP and NHANES 2009-2010. BMJ Open Diabetes Res Care. (2017) 5:e000304. doi: 10.1136/bmjdrc-2016-000304

11. Samad F, Harris M, Puskas CM, Ye M, Chia J, Chacko S, et al. Incidence of diabetes mellitus and factors associated with its development in HIVpositive patients over the age of 50. BMJ Open Diabetes Res Care. (2017) 5:e00457. doi: 10.1136/bmjdrc-2017-000457

12. Kalra S, Kalra B, Agrawal N, Unnikrishnan A. Understanding diabetes in patients with HIV/AIDS. Diabetol Metab Syndr. (2011) 3:2. doi: 10.1186/1758-5996-3-2

13. Glümer C, Carstensen B, Sandbæk A, Lauritzen T, Jørgensen T, BorchJohnsen K. A Danish diabetes risk score for targeted screening: the Inter99 study. Diabetes care. (2004) 27:727-33. doi: 10.2337/diacare.27.3.727

14. Rasmussen LD, Mathiesen ER, Kronborg G, Gerstoft J, Obel N. Risk of diabetes mellitus in persons with and without HIV: a Danish

\section{LIMITATION OF THE STUDY}

Clinical or experimental data reporting on the pathophysiology of GDM induced by placental and peripheral hormones in low risk pregnancy vs. HIV infected pregnancy are needed. Also more studies reporting on the haemostatic parameters in HIV infected vs. HIV uninfected pregnancies are needed more especially in Sub Saharan Africa which is a highly affected by HIV infection.

\section{AUTHOR CONTRIBUTIONS}

WNP conceptualized, wrote, and proof read the manuscript.

nationwide population-based cohort study. PLoS ONE. (2012 7:e44575. doi: 10.1371/journal.pone.0044575

15. Norris A, Dreher HM. Lipodystrophy syndrome: the morphologic and metabolic effects of antiretroviral therapy in HIV infection. J Assoc Nurses AIDS Care. (2004) 15:46-64. doi: 10.1177/1055329004271187

16. Fichtenbaum C, Hadigan C, Kotler D, Pierone JG, Sax P, Steinhart C, et al. Treatingmorphologic and metabolic complications in HIV-infected patients on antiretroviral therapy. A consensus statement of an advisory committee of the International Association of Physicians in AIDS Care. IAPAC Mon. (2005) 11:38-46.

17. Ben-Haroush A, Yogev Y, Hod M. Epidemiology of gestational diabetes mellitus and its association with Type 2 diabetes. Diabet Med. (2004) 21:10313. doi: 10.1046/j.1464-5491.2003.00985.x

18. Macaulay S, Dunger DB, Norris SA. Gestational diabetes mellitus in Africa: a systematic review. PLoS ONE. (2014) 9:e97871. doi: 10.1371/journal.pone.0097871

19. Machado ES, Krauss MR, Megazzini K, Coutinho CM, Kreitchmann R, Melo $\mathrm{VH}$, et al. Hypertension, preeclampsia and eclampsia among HIV-infected pregnant women from Latin America and Caribbean countries. J Infect. (2014) 68:572-80. doi: 10.1016/j.jinf.2013.12.018

20. Sebitloane HM, Moodley J, Sartorius B. Associations between HIV, highly active anti-retroviral therapy, and hypertensive disorders of pregnancy among maternal deaths in South Africa 2011-2013. Int J Gynaecol Obstet. (2017) 136:195-9. doi: 10.1002/ijgo.12038

21. Phoswa WN, Naicker T, Ramsuran V, Moodley J. Pre-eclampsia: the role of highly active antiretroviral therapy and immune markers. Inflamm Res. (2019) 68:47-57. doi: 10.1007/s00011-018-1190-3

22. Karpatkin S, Nardi M, Green D. Platelet and coagulation defects associated with HIV-1-infection. Thromb Haemost. (2002) 88:389-401. doi: 10.1055/s-0037-1613228

23. Friel TJ, Scadden DT, Leung L, Landaw SA. Hematologic manifestations of HIV infection: thrombocytopenia and coagulation abnormalities. Med Update. (2007) 46:1-12. doi: 10.5045/kjh.2011.46.4.253

24. Marathe PH, Gao HX, Close KL. American Diabetes Association standards of medical c are in diabetes (2017). J Diabetes. (2017) 9:3204. doi: 10.1111/1753-0407.12524

25. Federation ID. IDF Diabetes Atlas. Brussels: International Diabetes Federation. (2013)

26. Jiwani A, Marseille E, Lohse N, Damm P, Hod M, Kahn JG. Gestational diabetes mellitus: results from a survey of country prevalence and practices. J Matern Fetal Neonatal Med. (2012) 25:600-10. doi: 10.3109/14767058.2011.587921

27. Seshiah V, Balaji V, Balaji MS, Paneerselvam A, Arthi T, Thamizharasi M, et al. Prevalence of gestational diabetes mellitus in South India (Tamil Nadu): a community based study. JAPI. (2008) 56:329-33.

28. Moore TR, Hauguel-De Mouzon S, Catalano P. Diabetes in pregnancy. In: Maternal-Fetal Medicine: Principles and Practice. 5th ed. Philadelphia: Saunders (2004). p. 1023-61.

29. Adams S, Rheeder P. Screening for gestational diabetes mellitus in a South African population: prevalence, comparison of diagnostic criteria and the role of risk factors. S Afr Med J. (2017) 107:523-7. doi: 10.7196/SAMJ.2017.v107i6.12043 
30. Catalano Pa, Ehrenberg $\mathrm{H}$. The short-and long-term implications of maternal obesity on the mother and her offspring. BJOG. (2006) 113:112633. doi: $10.1111 /$ j.1471-0528.2006.00989.x

31. Jackson E. Glycosuria as an indication for glucose tolerance testing during pregnancy. South Afr Med J. (1979) 56:921-3.

32. Sacks DA, Hadden DR, Maresh M, Deerochanawong C, Dyer AR, Metzger $\mathrm{BE}$, et al. Frequency of gestational diabetes mellitus at collaborating centers based on IADPSG consensus panel-recommended criteria: the Hyperglycemia and Adverse Pregnancy Outcome (HAPO) Study. Diabetes care. (2012) 35:526-8. doi: 10.2337/dc11-1641

33. Nasiri-Amiri F, Sepidarkish M, Shirvani MA, Habibipour P, Tabari NSM. The effect of exercise on the prevention of gestational diabetes in obese and overweight pregnant women: a systematic review and meta-analysis. Diabetol Metabol Syndr. (2019) 11:1-14. doi: 10.1186/s13098-019-0470-6

34. American College of Obstetricians and Gynecologists Committee on Practice Bulletins-Obstetrics. Management guidelines for obstetrician-gynecologists. Gestational Diabetes Obstet Gynecol. (2001) 98:525-38.

35. Kalus AA, Chien AJ, Olerud JE. Diabetes mellitus and other endocrine diseases. In: Gabbe SG, Niebyl JR, Simpson JL, editors. Obstetrics: Normal and Problems Pregnancies. 3rd ed. New York, NY: Churchill-Livingstone (1996). p. 1037-81.

36. González-Tomé M, Ramos Amador J, Guillen S, Solís I, Fernández-Ibieta M, Munoz E, et al. Gestational diabetes mellitus in a cohort of HIV-1 infected women. HIV Med. (2008) 9:868-74. doi: 10.1111/j.1468-1293.2008.00639.x

37. Walli R, Herfort O, Michl GM, Demant T, Jäger H, Dieterle C, et al. Treatment with protease inhibitors associated with peripheral insulin resistance and impaired oral glucose tolerance in HIV-1-infected patients. AIDS. (1998) 12:F167-73. doi: 10.1097/00002030-199815000-00001

38. Carr A, Samaras K, Burton S, Law M, Freund J, Chisholm DJ, et al. A syndrome of peripheral lipodystrophy, hyperlipidaemia and insulin resistance in patients receiving HIV protease inhibitors. AIDS. (1998) 12:F51-F8. doi: 10.1097/00002030-199807000-00003

39. Justman JE, Benning L, Danoff A, Minkoff H, Levine A, Greenblatt RM, et al. Protease inhibitor use and the incidence of diabetes mellitus in a large cohort of HIV-infected women. J Acquir Immune Defic Syndr. (2003). 32:298-302. doi: 10.1097/00126334-200303010-00009

40. Dubé MP. Disorders of glucose metabolism in patients infected with human immunodeficiency virus. Clin Infect Dis. (2000) 31:1467-75. doi: 10.1086/317491

41. Brambilla AM, Novati R, Calori G, Meneghini E, Vacchini D, Luzi L, et al. Stavudine or indinavir-containing regimens are associated with an increased risk of diabetes mellitus in HIV-infected individuals. AIDS. (2003) 17:1993-5. doi: 10.1097/00002030-200309050-00022

42. Palacios R, Santos J, Ruiz J, González M, Márquez M. Factors associated with the development of diabetes mellitus in HIV-infected patients on antiretroviral therapy: a case-control study. AIDS. (2003) 17:9335. doi: 10.1097/00002030-200304110-00025

43. Aschkenazi S, Rochelson B, Bernasko J, Kaplan J. Insulin resistance complicating pregnancy in a human immunodeficiency virus-infected patient treated with protease inhibitors and corticosteroids. Obstetr Gynecol. (2003) 102:1210-2. doi: 10.1016/S0029-7844(03)00166-2

44. Hui DY. Effects of HIV protease inhibitor therapy on lipid metabolism. Prog Lipid Res. (2003) 42:81-92. doi: 10.1016/S0163-7827(02)00046-2

45. Monier PL, Wilcox R. Metabolic complications associated with the use of highly active antiretroviral therapy in HIV-1-infected adults. Am J Med Sci. (2004) 328:48-56. doi: 10.1097/00000441-200407000-00007

46. Jao J, Wong M, Van Dyke RB, Geffner M, Nshom E, Palmer $\mathrm{D}$, et al. Gestational diabetes mellitus in HIV-infected anduninfected pregnant women in Cameroon. Diabetes Care. (2013) 36:e141-2. doi: 10.2337/dc13-0968

47. Catalano PM, Huston L, Amini SB, Kalhan SC. Longitudinal changes in glucose metabolism during pregnancy in obese women with normal glucose tolerance and gestational diabetes mellitus. Am J Obstetr Gynecol. (1999) 180:903-16. doi: 10.1016/S0002-9378(99)70662-9

48. Catalano PM, Tyzbir ED, Wolfe RR, Calles J, Roman NM, Amini SB, et al. Carbohydrate metabolism during pregnancy in control subjects and women with gestational diabetes. Am J Physiol. (1993) 264:E607. doi: 10.1152/ajpendo.1993.264.1.E60
49. Barbour LA, McCurdy CE, Hernandez TL, Kirwan JP, Catalano PM, Friedman JE. Cellular mechanisms for insulin resistance in normal pregnancy and gestational diabetes. Diabetes Care. (2007) 30(Suppl. 2):S1129. doi: $10.2337 / \mathrm{dc} 07$-s202

50. Ryan EA, Enns L. Role of gestational hormones in the induction of insulin resistance. J Clin Endocrinol Metab. (1988) 67:341-7. doi: 10.1210/jcem-67-2-341

51. Colomiere M, Permezel M, Riley C, Desoye G, Lappas M. Defective insulin signaling in placenta from pregnancies complicated by gestational diabetes mellitus. Eur J Endocrinol. (2009) 160:567-78. doi: 10.1530/EJE-09-0031

52. Jansson N, Rosario FJ, Gaccioli F, Lager S, Jones HN, Roos S, et al. Activation of placental mTOR signaling and amino acid transporters in obese women giving birth to large babies. J Clin Endocrinol Metabol. (2013) 98:10513. doi: 10.1210/jc.2012-2667

53. Ruiz-Palacios M, Prieto-Sánchez MT, Ruiz-Alcaraz AJ, Blanco-Carnero JE, Sanchez-Campillo M, Parrilla JJ, et al. Insulin treatment may alter fatty acid carriers in placentas from gestational diabetes subjects. Int J Mol Sci. (2017) 18:1203. doi: 10.3390/ijms18061203

54. Araújo JR, Keating E, Martel F. Impact of gestational diabetes mellitus in the maternal-to-fetal transport of nutrients. Curr Diab Rep. (2015) 15:1. doi: 10.1007/s11892-014-0569-y

55. Mendoza MC, Er EE, Blenis J. The Ras-ERK and PI3K-mTOR pathways: cross-talk and compensation. Trends Biochem Sci. (2011) 36:320-8. doi: 10.1016/j.tibs.2011.03.006

56. Knöfler M, Sooranna S, Daoud G, Whitley GS, Markert U, Xia Y, et al. Trophoblast signalling: knowns and unknowns-a workshop report. Placenta. (2005) 26:S49-51. doi: 10.1016/j.placenta.2005.02.001

57. Kampmann U, Knorr S, Fuglsang J, Ovesen P. Determinants of maternal insulin resistance during pregnancy: an updated overview. J Diabetes Res. (2019) 2019:5320156. doi: 10.1155/2019/5320156

58. Catalano P. Trying to understand gestational diabetes. Diabet Med. (2014) 31:273-81. doi: 10.1111/dme.12381

59. Brelje TC, Scharp DW, Lacy PE, Ogren L, Talamantes F, Robertson $\mathrm{M}$, et al. Effect of homologous placental lactogens, prolactins, and growth hormones on islet B-cell division and insulin secretion in rat, mouse, and human islets: implication for placental lactogen regulation of islet function during pregnancy. Endocrinology. (1993) 132:87987. doi: 10.1210/endo.132.2.8425500

60. Barbour LA, Shao J, Qiao L, Pulawa LK, Jensen DR, Bartke A, et al. Human placental growth hormone causes severe insulin resistance in transgenic mice. Am J Obstetr Gynecol. (2002) 186:512-7. doi: $10.1067 / \mathrm{mob} .2002 .121256$

61. Lombardo MF, De Angelis F, Bova L, Bartolini B, Bertuzzi F, Nano R, et al. Human placental lactogen (hPL-A) activates signaling pathways linked to cell survival and improves insulin secretion in human pancreatic islets. Islets. (2011) 3:250-8. doi: 10.4161/isl.3.5.16900

62. Handwerger $\mathrm{S}$. The growth hormone gene cluster: physiological actions and regulation during pregnancy. Growth Genet Horm. (2009) 25:1-8.

63. Rechler MM, Clemmons DR. Regulatory actions of insulin-like growth factor-binding proteins. Trends Endocrinol Metabol. (1998) 9:176-83. doi: 10.1016/S1043-2760(98)00047-2

64. Velegrakis A, Sfakiotaki M, Sifakis S. Human placental growth hormone in normal and abnormal fetal growth. Biomed Rep. (2017) 7:11522. doi: 10.3892/br.2017.930

65. Vasavada RC, Garcia-Ocaña A, Zawalich WS, Sorenson RL, Dann $\mathrm{P}$, Syed $\mathrm{M}$, et al. Targeted expression of placental lactogen in the beta cells of transgenic mice results in beta cell proliferation, islet mass augmentation, and hypoglycemia. J Biol Chem. (2000) 275:15399406. doi: $10.1074 / j b c .275 .20 .15399$

66. Parsons JA, Brelje TC, Sorenson RL. Adaptation of islets of Langerhans to pregnancy: increased islet cell proliferation and insulin secretion correlates with the onset of placental lactogen secretion. Endocrinology. (1992) 130:1459-66. doi: 10.1210/en.130.3.1459

67. Barbour LA, Shao J, Qiao L, Leitner W, Anderson M, Friedman JE, et al. Human placental growth hormone increases expression of the P85 regulatory unit of phosphatidylinositol 3-kinase and triggers severe insulin resistance in skeletal muscle. Endocrinology. (2004) 145:114450. doi: 10.1210/en.2003-1297 
68. Barbour LA, Rahman SM, Gurevich I, Leitner JW, Fischer SJ, Roper $\mathrm{MD}$, et al. Increased $\mathrm{P} 85 \alpha$ is a potent negative regulator of skeletal muscle insulin signaling and induces in vivo insulin resistance associated with growth hormone excess. J Biol Chem. (2005) 280:37489-94. doi: 10.1074/jbc.M506967200

69. Waters TP, Schultz BA, Mercer BM, Catalano PM. Effect of $17 \alpha-$ hydroxyprogesterone caproate on glucose intolerance in pregnancy. Obstetr Gynecol. (2009) 114:45-9. doi: 10.1097/AOG.0b013e3181a9454b

70. Nunes V, Portioli-Sanches E, Rosim MP, Araujo MdS, Praxedes-Garcia $\mathrm{P}$, Valle MMR, et al. Progesterone induces apoptosis of insulin-secreting cells: insights into the molecular mechanism. J Endocrinol. (2014) 221:27384. doi: 10.1530/JOE-13-0202

71. Egerman R, Ramsey R, Istwan N, Rhea D, Stanziano G. Maternal characteristics influencing the development of gestational diabetes in obese women receiving 17-alpha-hydroxyprogesterone caproate. J Obes. (2014) 2014:563243. doi: 10.1155/2014/563243

72. Kouhkan A, Khamseh ME, Moini A, Pirjani R, Valojerdi AE, Arabipoor A, et al. Predictive factors of gestational diabetes in pregnancies following assisted reproductive technology: a nested case-control study. Arch Gynecol Obstet. (2018) 298:199-206. doi: 10.1007/s00404-018-4772-y

73. Mohammadi T, Paknahad Z. Adiponectin concentration in gestational diabetic women: a case-control study. Clin Nutr Res. (2017) 6:26776. doi: $10.7762 / \mathrm{cnr} .2017 .6 .4 .267$

74. Kautzky-Willer A, Pacini G, Tura A, Bieglmayer C, Schneider B, Ludvik B, et al. Increased plasma leptin in gestational diabetes. Diabetologia. (2001) 44:164-72. doi: 10.1007/s001250051595

75. Soheilykhah S, Mojibian M, Rahimi-Saghand S, Rashidi M, Hadinedoushan H. Maternal serum leptin concentration in gestational diabetes. Taiwan J Obstet Gynecol. (2011) 50:149-53. doi: 10.1016/j.tjog.2011.01.034

76. Yang M, Peng S, Li W, Wan Z, Fan L, Du Y. Relationships between plasma leptin levels, leptin G2548A, leptin receptor Gln223Arg polymorphisms and gestational diabetes mellitus in Chinese population. Sci Rep. (2016) 6:1-6. doi: 10.1038/srep23948

77. Ekinci EI, Torkamani N, Ramchand SK, Churilov L, Sikaris KA, Lu ZX, et al. Higher maternal serum prolactin levels are associated with reduced glucose tolerance during pregnancy. J Diabetes Investig. (2017) 8:697700. doi: $10.1111 /$ jdi. 12634

78. Lacroix MC, Guibourdenche J, Frendo JL, Muller F, Evain-Brion D. Human placental growth hormone-a review. Placenta. (2002) 23 Suppl A:S8794. doi: 10.1053/plac.2002.0811

79. Higgins MF, Russell NE, Crossey PA, Nyhan KC, Brazil DP, McAuliffe FM. Maternal and fetal placental growth hormone and IGF axis in type 1 diabetic pregnancy. PLoS ONE. (2012) 7:e29164. doi: 10.1371/journal.pone.0029164

80. Heitritter SM, Solomon CG, Mitchell GF, Skali-Ounis N, Seely EW. Subclinical inflammation and vascular dysfunction in women with previous gestational diabetes mellitus. J Clin Endocrinol Metabol. (2005) 90:39838. doi: 10.1210/jc.2004-2494

81. Winzer C, Wagner O, Festa A, Schneider B, Roden M, Bancher-Todesca D, et al. Plasma adiponectin, insulin sensitivity, and subclinical inflammation in women with prior gestational diabetes mellitus. Diabetes Care. (2004) 27:1721-7. doi: 10.2337/diacare.27.7.1721

82. Cusi K, Maezono K, Osman A, Pendergrass M, Patti ME, Pratipanawatr $\mathrm{T}$, et al. Insulin resistance differentially affects the PI 3-kinase-and MAP kinase-mediated signaling in human muscle. J Clin Invest. (2000) 105:31120. doi: 10.1172/JCI7535

83. Grimmsmann T, Levin K, Meyer M, Beck-Nielsen H, Klein H. Delays in insulin signaling towards glucose disposal in human skeletal muscle. $J$ Endocrinol. (2002) 172:645-51. doi: 10.1677/joe.0.1720645

84. Costrini N, Kalkhoff R. Relative effects of pregnancy, estradiol, and progesterone on plasma insulin and pancreatic islet insulin secretion. J Clin Invest. (1971) 50:992-9. doi: 10.1172/JCI106593

85. Straub SG, Sharp GW, Meglasson MD, De Souza CJ. Progesterone inhibits insulin secretion by a membrane delimited, non-genomic action. Biosci Rep. (2001) 21:653-66. doi: 10.1023/A:1014773010350

86. Rouholamin S, Zarean E, Sadeghi L. Evaluation the effect of 17alpha hydroxyprogesterone caproate on gestational diabetes mellitus in pregnant women at risk for preterm birth. Advan Biomed Res. (2015) 4:242. doi: 10.4103/2277-9175.168609
87. Rebarber A, Istwan NB, Russo-Stieglitz K, Cleary-Goldman J, Rhea DJ, Stanziano GJ, et al. Increased incidence of gestational diabetes in women receiving prophylactic $17 \alpha$-hydroxyprogesterone caproate for prevention of recurrent preterm delivery. Diabetes Care. (2007) 30:227780. doi: $10.2337 / \mathrm{dc} 07-0564$

88. Rosta K, Ott J, Kelemen F, Temsch W, Lahner T, Reischer T, et al. Is vaginal progesterone treatment associated with the development of gestational diabetes? A retrospective case-control study. Arch Gynecol Obstet. (2018) 298:1079-84. doi: 10.1007/s00404-018-4895-1

89. Chandran M, Phillips SA, Ciaraldi T, Henry RR. Adiponectin: more than just another fat cell hormone? Diabetes Care. (2003) 26:244250. doi: $10.2337 /$ diacare.26.8.2442

90. Ziemke F, Mantzoros CS. Adiponectin in insulin resistance: lessons from translational research. Am J Clin Nutr. (2010) 91:258S-61S. doi: 10.3945/ajcn.2009.28449C

91. Karpe F. Insulin resistance by adiponectin deficiency: is the action in skeletal muscle? Diabetes. (2013) 62:701-2. doi: 10.2337/db12-1519

92. Carpenter MW. Gestational diabetes, pregnancy hypertension, and late vascular disease. Diabetes Care. (2007) 30(Suppl. 2):S246-S50. doi: $10.2337 / \mathrm{dc} 07-\mathrm{s} 224$

93. Retnakaran R, Hanley AJ, Raif N, Connelly PW, Sermer M, Zinman B. Reduced adiponectin concentration in women with gestational diabetes: a potential factor in progression to type 2 diabetes. Diabetes Care. (2004) 27:799-800. doi: 10.2337/diacare.27.3.799

94. Yadav A, Kataria MA, Saini V, Yadav A. Role of leptin and adiponectin in insulin resistance. Clin Chim Acta. (2013) 417:80-4. doi: 10.1016/j.cca.2012.12.007

95. Yamauchi T, Kamon J, Minokoshi Ya, Ito Y, Waki H, Uchida S, et al. Adiponectin stimulates glucose utilization and fatty-acid oxidation by activating AMP-activated protein kinase. Nat Med. (2002) 8:1288. doi: $10.1038 / \mathrm{nm} 788$

96. Söderberg S, Zimmet P, Tuomilehto J, Chitson P, Gareeboo H, Alberti $\mathrm{K}$, et al. Leptin predicts the development of diabetes in Mauritian men, but not women: a population-based study. Int J Obes. (2007) 31:1126. doi: 10.1038/sj.ijo.0803561

97. Zhang Y, Proenca R, Maffei M, Barone M, Leopold L, Friedman JM. Positional cloning of the mouse obese gene and its human homologue. Nature. (1994) 372:425. doi: 10.1038/372425a0

98. Lam NT, Lewis JT, Cheung AT, Luk CT, Tse J, Wang J, et al. Leptin increases hepatic insulin sensitivity and protein tyrosine phosphatase $1 \mathrm{~B}$ expression. Mol Endocrinol. (2004) 18:1333-45. doi: 10.1210/me.2002-0193

99. Seufert J, Kieffer TJ, Habener JF. Leptin inhibits insulin gene transcription and reverses hyperinsulinemia in leptin-deficient ob/ob mice. Proc Nat Acad Sci. (1999) 96:674-9. doi: 10.1073/pnas.96.2.674

100. Stephens TW, Basinski M, Bristow PK, Bue-Valleskey JM, Burgett SG, Craft $\mathrm{L}$, et al. The role of neuropeptide $\mathrm{Y}$ in the antiobesity action of the obese gene product. Nature. (1995) 377:530. doi: 10.1038/377530a0

101. Weigle DS, Bukowski TR, Foster DC, Holderman S, Kramer JM, Lasser G, et al. Recombinant ob protein reduces feeding and body weight in the ob/ob mouse. J Clin Invest. (1995) 96:2065-70. doi: 10.1172/JCI118254

102. Kulkarni RN, Wang Z-L, Wang R-M, Hurley JD, Smith DM, Ghatei MA, et al. Leptin rapidly suppresses insulin release from insulinoma cells, rat and human islets and, in vivo, in mice. J Clin Invest. (1997) 100:272936. doi: $10.1172 /$ JCI119818

103. Poitout V, Rouault C, Guerre-Millo Ml, Briaud I, Reach GR. Inhibition of insulin secretion by leptin in normal rodent islets of Langerhans. Endocrinology. (1998) 139:822-6. doi: 10.1210/endo.139.3.5812

104. Zhao AZ, Bornfeldt KE, Beavo JA. Leptin inhibits insulin secretion by activation of phosphodiesterase 3B. J Clin Invest. (1998) 102:86973. doi: $10.1172 /$ JCI3920

105. Ahren B, Havel PJ. Leptin inhibits insulin secretion induced by cellular cAMP in a pancreatic B cell line (INS-1 cells). Am J Physiol. (1999) 277:R959-66. doi: 10.1152/ajpregu.1999.277. 4.R959

106. Lee JW, Swick AG, Romsos DR. Leptin constrains phospholipase Cprotein kinase C-induced insulin secretion via a phosphatidylinositol 3-kinase-dependent pathway. Exp Biol Med. (2003) 228:17582. doi: $10.1177 / 153537020322800207$ 
107. Wannamethee SG, Lowe GD, Rumley A, Cherry L, Whincup PH, Sattar N. Adipokines and risk of type 2 diabetes in older men. Diabetes Care. (2007) 30:1200-5. doi: 10.2337/dc06-2416

108. Bandaru P, Shankar A. Association between plasma leptin levels and diabetes mellitus. Metab Syndr Relat Disord. (2011) 9:19-23. doi: 10.1089/met.2010.0037

109. Soliman AT, Omar M, Assem HM, Nasr IS, Rizk MM, El Matary W, et al. Serum leptin concentrations in children with type 1 diabetes mellitus: relationship to body mass index, insulin dose, and glycemic control. Metabolism. (2002) 51:292-6. doi: 10.1053/meta.2002.30502

110. Haffner SM, Stern MP, Miettinen H, Wei M, Gingerich RL. Leptin concentrations in diabetic and non-diabetic Mexican-Americans. Diabetes. (1996) 45:822-4. doi: 10.2337/diab.45.6.822

111. Maahs DM, Hamman RF, D'Agostino R Jr, Dolan LM, Imperatore G, Lawrence JM, et al. The association between adiponectin/leptin ratio and diabetes type: the SEARCH for Diabetes in Youth Study. J Pediatr. (2009) 155:133-5.e1. doi: 10.1016/j.jpeds.2008.12.048

112. Welsh P, Murray HM, Buckley BM, De Craen AJ, Ford I, Jukema JW, et al. Leptin predicts diabetes but not cardiovascular disease: results from a large prospective study in an elderly population. Diabetes Care. (2009) 32:308-10. doi: 10.2337/dc08-1458

113. Mcneely MJ, Boyko EJ, Weigle DS, Shofer JB, Chessler SD, Leonnetti DL, et al. Association between baseline plasma leptin levels and subsequent development of diabetes in Japanese Americans. Diabetes Care. (1999) 22:6570. doi: $10.2337 /$ diacare.22.1.65

114. Bhattacharya S, Kalra S, Dutta D, Khandelwal D, Singla R. The interplay between pituitary health and diabetes mellitus-the need for 'Hypophyseovigilance'. Eur Endocrinol. (2020) 16:25. doi: 10.17925/EE.2020.16.1.25

115. Park S, Kim DS, Daily JW, Kim SH. Serum prolactin concentrations determine whether they improve or impair $\beta$-cell function and insulin sensitivity in diabetic rats. Diabetes Metab Res Rev. (2011) 27:56474. doi: 10.1002/dmrr.1215

116. Wang T, Lu J, Xu Y, Li M, Sun J, Zhang J, et al. Circulating prolactin associates with diabetes and impaired glucose regulation: a population-based study. Diabetes Care. (2013) 36:1974-80. doi: 10.2337/dc12-1893

117. Wang T, Xu Y, Xu M, Ning G, Lu J, Dai M, et al. Circulating Prolactin and Risk of Type 2 Diabetes: A Prospective Study. Am J Epidemiol. (2016) 184:295-301. doi: 10.1093/aje/kwv326

118. Daimon M, Kamba A, Murakami H, Mizushiri S, Osonoi S, Yamaichi M, et al. Association between serum prolactin levels and insulin resistance in non-diabetic men. PLoS ONE. (2017) 12:e0175204. doi: 10.1371/journal.pone.0175204

119. Retnakaran R, Ye C, Kramer CK, Connelly PW, Hanley AJ, Sermer $\mathrm{M}$, et al. Maternal serum prolactin and prediction of postpartum $\beta$-cell function and risk of prediabetes/Diabetes. Diabetes Care. (2016) 39:12508. doi: 10.2337/dc16-0043

120. Krishnaveni GV, Veena SR, Jones A, Srinivasan K, Osmond C, Karat SC, et al. Exposure to maternal gestational diabetes is associated with higher cardiovascular responses to stress in adolescent indians. J Clin Endocrinol Metab. (2015) 100:986-93. doi: 10.1210/jc.2014-3239

121. Kirwan JP, Hauguel-De Mouzon S, Lepercq J, Challier J-C, Huston-Presley L, Friedman JE, et al. TNF- $\alpha$ is a predictor of insulin resistance in human pregnancy. Diabetes. (2002) 51:2207-13. doi: 10.2337/diabetes.51.7.2207

122. Fowler MG, Qin M, Fiscus SA, Currier JS, Flynn PM, Chipato T, et al. Benefits and risks of antiretroviral therapy for perinatal HIV prevention. $N$ Engl J Med. (2016) 375:1726-37. doi: 10.1056/NEJMoa1511691

123. Sibiude J, Warszawski J, Tubiana R, Dollfus C, Faye A, Rouzioux C, et al. Premature delivery in HIV-infected women starting protease inhibitor therapy during pregnancy: role of the ritonavir boost? Clin Infect Dis. (2012) 54:1348-60. doi: 10.1093/cid/cis198

124. Van Dyke RB, Chadwick EG, Hazra R, Williams PL, Seage GR III. The PHACS SMARTT study: assessment of the safety of in utero exposure to antiretroviral drugs. Front Immunol. (2016) 7:199. doi: 10.3389/fimmu.2016.00199

125. Kim M, Park HJ, Seol JW, Jang JY, Cho YS, Kim KR, et al. VEGF-A regulated by progesterone governs uterine angiogenesis and vascular remodelling during pregnancy. EMBO Mol Med. (2013) 5:141530. doi: $10.1002 / \mathrm{emmm} .201302618$
126. Chen JZ-J, Wong MH, Brennecke SP, Keogh RJ. The effects of human chorionic gonadotrophin, progesterone and oestradiol on trophoblast function. Mol Cell Endocrinol. (2011) 342:7380. doi: 10.1016/j.mce.2011.05.034

127. Amirhessami-Aghili N, Spector SA. Human immunodeficiency virus type 1 infection of human placenta: potential route for fetal infection. J Virol. (1991) 65:2231-6. doi: 10.1128/JVI.65.5.2231-2236.1991

128. Papp E, Balogun K, Banko N, Mohammadi H, Loutfy M, Yudin $\mathrm{MH}$ et al. Low prolactin and high 20- $\alpha$-hydroxysteroid dehydrogenase levels contribute to lower progesterone levels in HIV-infected pregnant women exposed to protease inhibitor-based combination antiretroviral therapy. J Infect Dis. (2016) 213:1532-40. doi: 10.1093/infdis/ jiw004

129. Papp E, Mohammadi H, Loutfy MR, Yudin MH, Murphy KE, Walmsley $\mathrm{SL}$, et al. HIV protease inhibitor use during pregnancy is associated with decreased progesterone levels, suggesting a potential mechanism contributing to fetal growth restriction. J Infect Dis. (2014) 211:10 8. doi: 10.1093/infdis/jiu393

130. Mohammadi H, Papp E, Cahill L, Rennie M, Banko N, Pinnaduwage L, et al. HIV antiretroviral exposure in pregnancy induces detrimental placenta vascular changes that are rescued by progesterone supplementation. Sci Rep. (2018) 8:6552. doi: 10.1038/s41598-018-24680-w

131. Oral EA, Simha V, Ruiz E, Andewelt A, Premkumar A, Snell P, et al. Leptinreplacement therapy for lipodystrophy. N Engl J Med. (2002) 346:5708. doi: 10.1056/NEJMoa012437

132. van Crevel R, Karyadi E, Netea MG, Verhoef H, Nelwan RH, West CE, et al. Decreased plasma leptin concentrations in tuberculosis patients are associated with wasting and inflammation. J Clin Endocrinol Metab. (2002) 87:758-63. doi: 10.1210/jcem.87.2.8228

133. Hardie L, Trayhurn P, Abramovich D, Fowler P. Circulating leptin in women a longitudinal study in the menstrual cycle and during pregnancy. Clin Endocrinol. (1997) 47:101-6. doi: 10.1046/j.1365-2265.1997.2441017.x

134. Nagy GS, Tsiodras S, Martin LD, Avihingsanon A, Gavrila A, Hsu WC, et al. Human immunodeficiency virus type 1-related lipoatrophy and lipohypertrophy are associated with serum concentrations of leptin. Clin Infect Dis. (2003) 36:795-802. doi: 10.1086/367859

135. Haffejee F, Naicker T, Singh M, Moodley J. Placental leptin in HIVassociated preeclampsia. Eur J Obstetr Gynecol Reprod Biol. (2013) 171:2716. doi: 10.1016/j.ejogrb.2013.09.027

136. Montero A, Bottasso OA, Luraghi MaR, Giovannoni AG, Sen L. Association between high serum prolactin levels and concomitant infections in HIV-infected patients. Hum Immunol. (2001) 62:191-6. doi: 10.1016/S0198-8859(00)00245-7

137. Raushaniya B, Tatyana M, Aleksandr S, Maryam Z. Prolactin and cortisol hormones level in patients with HIV and AIDS. Int Sci Rev. (2016) 21:74-8. Available online at: https://cyberleninka.ru/article/n/prolactin-and-cortisolhormones-level-in-patients-with-hiv-and-aids

138. Collazos J, Ibarra S, Martinez E, Mayo J. Serum prolactin concentrations in patients infected with human immunodeficiency virus. HIV Clin Trials. (2002) 3:133-8. doi: 10.1310/QAQQ-XTCJ-8AL4-6F5P

139. Okeke CU, Agbasi PU, Okorie H, Ezeiruaku F. Effect of antiretroviral drugs on prolactin in HIV infected pregnant women. Int J Biol Chem Sci. (2014) 8:1234-8. doi: 10.4314/ijbcs.v8i3.34

140. Collazos J, Mayo J, Martínez E, Ibarra S. Serum cortisol in HIV-infected patients with and without highly active antiretroviral therapy. AIDS. (2003) 17:123-6. doi: 10.1097/00002030-200301030-00018

141. Esemu LF, Yuosembom EK, Fang R, Rasay S, Fodjo BA, Nguasong JT, et al. Impact of HIV-1 infection on the IGF-1 axis and angiogenic factors in pregnant Cameroonian women receiving antiretroviral therapy. PLoS ONE (2019) 14:e0215825. doi: 10.1371/journal.pone.0215825

142. Laron Z. Insulin-like growth factor 1 (IGF-1): a growth hormone. Mol Pathol. (2001) 54:311. doi: $10.1136 / \mathrm{mp} .54 .5 .311$

143. Mol BW, Roberts CT, Thangaratinam S, Magee LA, De Groot CJ, Hofmeyr GJ. Pre-eclampsia. Lancet. (2016) 387:9991011. doi: 10.1016/S0140-6736(15)00070-7

144. Duley L, editor. The global impact of pre-eclampsia and eclampsia. In: Seminars in Perinatology. Bradford: Elsevier (2009). doi: 10.1053/j.semperi.2009.02.010 
145. Moodley J, editor. Maternal deaths due to hypertensive disorders of pregnancy: data from the 2014-2016 Saving Mothers' Report. In: Obstetrics and Gynaecology Forum. Durban: In House Publications (2018).

146. Moodley J, Soma-Pillay P, Buchmann E, Pattinson R. Hypertensive disorders in pregnancy: 2019. National guideline. S Afr Med J. (2019) 109:12723. doi: 10.7196/SAMJ.2019.v109i3.14104

147. Anand S. Perinatal outcome in growth retarted babies born to normotensive and hypertensive mothers: a prospective study. Peoples J Sci Res. (2012) 5:248. Available online at: http://imsear.searo.who.int/handle/123456789/140314

148. Redman CW, Sargent IL. Immunology of pre-eclampsia. Am J Reprod Immunol. (2010) 63:534-43. doi: 10.1111/j.1600-0897.2010.00831.x

149. Udenze I, Amadi C, Awolola N, Makwe CC. The role of cytokines as inflammatory mediators in preeclampsia. Pan Afr Med J. (2015) 20:219. doi: 10.11604/pamj.2015.20.219.5317

150. Cakmak HA, Dincgez Cakmak B, Abide Yayla C, Inci Coskun E, Erturk $\mathrm{M}$, Keles I. Assessment of relationships between novel inflammatory markers and presence and severity of preeclampsia: Epicardial fat thickness, pentraxin-3, and neutrophil-to-lymphocyte ratio. Hypertens Pregnancy. (2017) 36:233-9. doi: 10.1080/10641955.2017.1321016

151. Vilchez G, Londra L, Hoyos LR, Sokol R, Bahado-Singh R. Intrapartum mean platelet volume is not a useful predictor of new-onset delayed postpartum pre-eclampsia. Int J Gynaecol Obstet. (2015) 131:59-62. doi: 10.1016/j.ijgo.2015.04.037

152. Aggarwal R, Jain AK, Mittal P, Kohli M, Jawanjal P, Rath G. Association of pro- and anti-inflammatory cytokines in preeclampsia. J Clin Lab Anal. (2019) 33:e22834. doi: 10.1002/jcla.22834

153. AlSheeha MA, Alaboudi RS, Alghasham MA, Iqbal J, Adam I. Platelet count and platelet indices in women with preeclampsia. Vasc Health Risk Manag. (2016) 12:477. doi: 10.2147/VHRM.S120944

154. Lockwood CJ, Yen C-F, Basar M, Kayisli UA, Martel M, Buhimschi I, et al. Preeclampsia-related inflammatory cytokines regulate interleukin6 expression in human decidual cells. Am J Pathol. (2008) 172:15719. doi: 10.2353/ajpath.2008.070629

155. Bramham K, Parnell B, Nelson-Piercy C, Seed PT, Poston L, Chappell LC. Chronic hypertension and pregnancy outcomes: systematic review and meta-analysis. BMJ. (2014) 348:g2301. doi: 10.1136/bmj.g2301

156. Maharaj NR, Phulukdaree A, Nagiah S, Ramkaran P, Tiloke C, Chuturgoon AA. Pro-inflammatory cytokine levels in HIV infected and uninfected pregnant women with and without preeclampsia. PLoS ONE. (2017) 12:e0170063. doi: 10.1371/journal.pone.0170063

157. Kalumba VM, Moodley J, Naidoo TD. Is the prevalence of pre-eclampsia affected by HIV/AIDS? A retrospective case-control study. Cardiovasc J Afr. (2013) 24:24-7. doi: 10.5830/CVJA-2012-078

158. Raman RT, Manimaran D, Rachakatla P, Bharathi K, Afroz T, Sagar R. Study of basic coagulation parameters among HIV patients in correlation to CD4 counts and ART status. J Clin Diagn Res. (2016) 10:EC046. doi: 10.7860/JCDR/2016/17459.7718

159. Possomato-Vieira JS, Khalil RA. Mechanisms of endothelial dysfunction in hypertensive pregnancy and preeclampsia. Adv Pharmacol. (2016) 77:361431. doi: 10.1016/bs.apha.2016.04.008

160. Ciccone M, Carbonara R, Giardinelli F, Zito A, Ricci G, Dentamaro I, et al. Gestational hypertension: endothelial dysfunction as a marker of pre-eclampsia. Eur Heart J. (2017) 38:ehx502.P2632. doi: 10.1093/eurheartj/ehx502.P2632

161. Roberts JM, Pearson G, Cutler J, Lindheimer M. Summary of the NHLBI working group on research on hypertension during pregnancy. Hypertension. (2003) 41:437-45. doi: 10.1161/01.HYP.0000054981.03589.E9

162. Thadhani RI, Johnson RJ, Karumanchi SA. Hypertension during pregnancy: a disorder begging for pathophysiological support. Am Heart Assoc. (2005) doi: 10.1161/01.HYP.0000188701.24418.64

163. Roberts J. Gammill HS: preeclampsia: recent insights. Hypertension. (2005) 46:1243-9. doi: 10.1161/01.HYP.0000188408.49896.c5

164. Granger JP, Alexander BT, Llinas MT, Bennett WA, Khalil RA. Pathophysiology of hypertension during preeclampsia linking placental ischemia with endothelial dysfunction. Hypertension. (2001) 38:718-22. doi: 10.1161/01.HYP.38.3.718

165. Adu-Bonsaffoh K, Antwi DA, Gyan B, Obed SA. Endothelial dysfunction in the pathogenesis of pre-eclampsia in Ghanaian women. BMC Physiol. (2017) 17:5. doi: 10.1186/s12899-017-0029-4
166. Germain AM, Romanik MC, Guerra I, Solari S, Reyes MaS, Johnson RJ, et al. Endothelial dysfunction: a link among preeclampsia, recurrent pregnancy loss, and future cardiovascular events? Hypertension. (2007) 49:90-5. doi: 10.1161/01.HYP.0000251522.18094.d4

167. Chambers JC, Fusi L, Malik IS, Haskard DO, De Swiet M, Kooner IS. Association of maternal endothelial dysfunction with preeclampsia. JAMA. (2001) 285:1607-12. doi: 10.1001/jama.285.12.1607

168. Carbillon L. Uterine artery Doppler and changes in endothelial function before clinical disease in preeclamptic women. Hypertension. (2006) 47:e16. doi: 10.1161/01.HYP.0000208994.69007.3e

169. Saleh L, Verdonk K, Visser W, van den Meiracker AH, Danser AH. The emerging role of endothelin-1 in the pathogenesis of pre-eclampsia. Ther $A d v$ Cardiovasc Dis. (2016) 10:282-93. doi: 10.1177/1753944715624853

170. Jain A. Endothelin-1: a key pathological factor in pre-eclampsia? Reprod Biomed Online. (2012) 25:443-9. doi: 10.1016/j.rbmo.2012.07.014

171. Verdonk K, Saleh L, Lankhorst S, Smilde JI, Van Ingen MM, Garrelds IM, et al. Association studies suggest a key role for endothelin1 in the pathogenesis of preeclampsia and the accompanying reninangiotensin-aldosterone system suppression. Hypertension. (2015) 65:131623. doi: 10.1161/HYPERTENSIONAHA.115.05267

172. Bakrania B, Duncan J, Warrington JP, Granger JP. The endothelin type A receptor as a potential therapeutic target in preeclampsia. Int J Mol Sci. (2017) 18:522. doi: 10.3390/ijms18030522

173. Granger JP, Alexander BT, Llinas MT, Bennett WA, Khalil RA. Pathophysiology of preeclampsia: linking placental ischemia/hypoxia with microvascular dysfunction. Microcirculation. (2002) 9:14760. doi: 10.1038/sj.mn.7800137

174. Roberts JM, Von Versen-Hoeynck F. Maternal fetal/placental interactions and abnormal pregnancy outcomes. Hypertension. (2007) 49:15-6. doi: 10.1161/01.HYP.0000251523.44824.02

175. Taylor RN, Varma M, Teng NN, Roberts JM. Women with preeclampsia have higher plasma endothelin levels than women with normal pregnancies. J Clin Endocrinol Metab. (1990) 71:1675-7. doi: 10.1210/jcem-7 1-6-1675

176. Powe CE, Levine RJ, Karumanchi SA. Preeclampsia, a disease of the maternal endothelium: the role of antiangiogenic factors and implications for later cardiovascular disease. Circulation. (2011) 123:285669. doi: 10.1161/CIRCULATIONAHA.109.853127

177. Cipolla MJ. Cerebrovascular function in pregnancy and eclampsia. Hypertension. (2007) 50:1424. doi: 10.1161/HYPERTENSIONAHA.106.079442

178. Euser AG, Cipolla MJ. Cerebral blood flow autoregulation and edema formation during pregnancy in anesthetized rats. Hypertension. (2007) 49:334-40. doi: 10.1161/01.HYP.0000255791.54655.29

179. Lind Malte A, Uldbjerg N, Wright D, Torring N. Prediction of severe pre-eclampsia/HELLP syndrome by combination of sFlt-1, CT-pro-ET-1, and blood pressure: exploratory study. Ultrasound Obstet Gynecol. (2018) 51:768-74. doi: 10.1002/uog.17561

180. Morris R, Spencer S-K, Kyle PB, Williams JM, Harris As, Owens MY, et al. Hypertension in an animal model of HELLP syndrome is associated with activation of endothelin 1. Reprod Sci. (2016) 23:4250. doi: 10.1177/1933719115592707

181. Brewer J, Martin J, Armstrong A, Blake P, Morris R, Owens M, et al. 775: posterior reversible encephalopathy syndrome (PRES) associated with eclampsia: the variable effects of therapeutic agents to accelerate safe recovery. Am J Obstetr Gynecol. (2012) 206:S342. doi: 10.1016/j.ajog.2011.10.793

182. Funderburg NT, Mayne E, Sieg SF, Asaad R, Jiang W, Kalinowska M, et al. Increased tissue factor expression on circulating monocytes in chronic HIV infection: relationship to in vivo coagulation and immune activation. Blood. (2010) 115:161-7. doi: 10.1182/blood-2009-03-210179

183. Hansen L, Parker I, Sutliff RL, Platt MO, Gleason RL. Endothelial dysfunction, arterial stiffening, and intima-media thickening in large arteries from HIV-1 transgenic mice. Ann Biomed Eng. (2013) 41:68293. doi: 10.1007/s10439-012-0702-5

184. Taremwa IM, Muyindike WR, Muwanguzi E, Boum Y. Prevalence of HIV-related thrombocytopenia among clients at Mbarara Regional Referral Hospital, Mbarara, southwestern Uganda. J Blood Med. (2015) 6:109. doi: 10.2147/JBM.S80857 
185. Jiang J, Fu W, Wang X, Lin PH, Yao Q, Chen C. HIV gp120 induces endothelial dysfunction in tumour necrosis factor- $\alpha$-activated porcine and human endothelial cells. Cardiovasc Res. (2010) 87:36674. doi: $10.1093 / \mathrm{cvr} / \mathrm{cvq} 013$

186. Solages A, Vita JA, Thornton DJ, Murray J, Heeren T, Craven DE, et al. Endothelial function in HIV-infected persons. Clin Infect Dis. (2006) 42:1325-32. doi: 10.1086/5 03261

187. Rajendran P, Rengarajan T, Thangavel J, Nishigaki Y, Sakthisekaran D, Sethi $\mathrm{G}$, et al. The vascular endothelium and human diseases. Int J Biol Sci. (2013) 9:1057. doi: 10.7150/ijbs.7502

188. Lafeuillade A, Alessi M, Poizot-Martin I, Boyer-Neumann C, Zandotti C, Quilichini R, et al. Endothelial cell dysfunction in HIV infection. J Acquir Immune Defic Syndr. (1992) 5:127-31.

189. Shen Y-MP, Frenkel EP. Thrombosis and a hypercoagulable state in HIV-infected patients. Clin Appl Thromb Hemost. (2004) 10:27780. doi: $10.1177 / 107602960401000311$

190. Szpera-Gozdziewicz A, Majcherek M, Boruczkowski M, Gozdziewicz T, Dworacki G, Wicherek L, et al. Circulating endothelial cells, circulating endothelial progenitor cells, and von Willebrand factor in pregnancies complicated by hypertensive disorders. Am J Reprod Immunol. (2017) 77:e12625. doi: 10.1111/aji.12625

191. Vinayagam V, Bobby Z, Habeebullah S, Chaturvedula L, Bharadwaj SK. Plasma markers of endothelial dysfunction in patients with hypertensive disorders of pregnancy: a pilot study in a South Indian population. J Matern Fetal Neonatal Med. (2016) 29:2077-82. doi: 10.3109/14767058.2015.1075200

Conflict of Interest: The author declares that the research was conducted in the absence of any commercial or financial relationships that could be construed as a potential conflict of interest.

Copyright (C) 2021 Phoswa. This is an open-access article distributed under the terms of the Creative Commons Attribution License (CC BY). The use, distribution or reproduction in other forums is permitted, provided the original author(s) and the copyright owner(s) are credited and that the original publication in this journal is cited, in accordance with accepted academic practice. No use, distribution or reproduction is permitted which does not comply with these terms. 